\title{
FEEDBACK OF BIOCHEMICAL INDEXES OF BLOOD SUGAR CONTROL BY SWIMMING EXERCISE
}

\author{
FEEDBACK DOS ÍNDICES BIOQUIIMICOS DE CONTROLE DE AÇÚCAR NO SANGUE POR EXERCICIOS \\ DENATAÇÃO
}

\author{
FEEDBACKDE LOS ÍNDICES BIOQUÍMICOS DEL CONTROL DEL AZÚCAREN SANGRE MEDIANTE \\ ELEJERCICIO DENATACIÓN
}

\author{
Yansheng Zhang' (D) \\ (Physical Education Professional) \\ Chunying Zhao ${ }^{2}$ \\ (Physician) \\ 1. Chinese Academy of Labour and \\ Social Security, Beijing, China. \\ 2. Linyi People's Hospita, Linyi, \\ China. \\ Correspondence: \\ Chunying Zhao \\ Linyi, China.lywszys@163.com
}

\begin{abstract}
Introduction: According to the metabolic characteristics of ultra-long-distance swimming and the characteristics of energy utilization and absorption during exercise, we have formulated a nutritional supplement plan for crossing to study the influence of swimming sports on blood sugar and give biochemical feedback indicators. Objective: To lay a foundation for studying the nutrition supplement rules during long-term exercise by taking the athletes'blood after training to determine the changes in blood sugar, adjusting and determining the nutritional supplement plan during training. Methods: We monitor athletes' physical function changes and biochemical indicators during training and study the changes of these biochemical indicators and athletes' physical functions after long-term swimming exercises to scientifically arrange the exercise intensity and load during the training period. Results: The urine indexes after exercise did not change much, reflecting the exercise load's low intensity. The changes in blood lactic acid and blood urea indexes after exercise also confirmed this. During the training period, the athletes' hemoglobin and red blood cell parameters are in the ideal range, indicating that the athlete's physical function is in good condition. During the training period, the training load intensity and load are reasonable according to ultra-long-distance swimming's energy supply characteristics. After training, the changes in blood glucose indicators reflect that the nutritional supplement program we formulated for athletes is reasonable and feasible. Conclusions: By monitoring the blood sugar and biochemical indicators of swimmers, it can help athletes to arrange exercise intensity scientifically and load during the training period, to better carry out open water competitions in China, and to arrange training and scientific nutrition during the training period scientifically. Lay the foundation for the establishment of nutrition supplement theory and training theory for super long-time sports. Level of evidence Il; Therapeutic studies - investigation of treatment results.
\end{abstract}

Keywords: Swimming; Biochemitry; Blood glucose; Erythrocytes; Physical education and training.

\section{RESUMO}

Introducción: De acuerdo con las características metabólicas de la natación de ultra larga distancia y las características de utilización y absorción de energía durante el ejercicio, hemos formulado un plan de complementos nutricionales para estudiar la influencia de los deportes de natación en el azúcar en sangre y dar indicadores de retroalimentación bioquímica. Objetivo: Sentar las bases para el estudio de las reglas de los suplementos nutricionales durante el ejercicio a largo plazo mediante la extracción de sangre de los atletas después del entrenamiento para determinar los cambios en el azúcar en sangre, ajustando y determinan do el plan de suplementos nutricionales durante el entrenamiento. Métodos: monitoreamos los cambios en la función física de los atletas y los indicadores bioquímicos durante el entrenamiento y estudiamos los cambios de estos indicadores bioquímicos y las funciones físicas de los atletas después de ejercicios de natación de larga distancia para organizar cientificamente la intensidad y la carga del ejercicio durante el período de entrenamiento. Resultados: Los índices de orina después del ejercicio no cambiaron mucho, lo que refleja la baja intensidad de la carga de ejercicio. Los cambios en los índices de ácido láctico y urea en sangre después del ejercicio también lo confirmaron. Durante el período de entrenamiento, los parámetros de hemoglobina y glóbulos rojos de los atletas están en el rango ideal, lo que indica que la función fisica del a tleta está en buenas condiciones. Durante el período de entrenamiento, la intensidad de la carga de entrenamiento y la carga son razonables de acuerdo con las características de suministro de energía de la natación de ultra larga distancia. Después del entrenamiento, los cambios en los indicadores de glucosa en sangre reflejan que el programa de suplementos nutricionales que formulamos para los atletas es razonabley factible. Conclusiones: monitorear los indicadores bioquímicos y de azúcar en sangre de los nadadores, puede ayudar a los atletas a organizar científicamente la intensidad del ejercicio y la carga durante el periodo de entrenamiento, a realizar mejor las competiciones en aguas abiertas en China y a organizar el entrenamiento y la nutrición científica durante el período de entrenamiento. Sentar las bases para el establecimiento de la teoría de los suplementos nutricionales y la teoría del entrenamiento para deportes de larga duración. Nivel de evidencia Il; Estudios terapéuticos: investigación de los resultados del tratamiento.

Descriptores: Natação; Bioquímica; Glicemia; Eritrócitos; Educação física e treinamento. 


\section{RESUMO}

Introdução: De acordo com as características metabólicas da natação de ultra longa distância e as características de utilização e absorção de energia durante o exercício, formulamos um plano de suplemento nutricional para estudar a influência dos esportes de natação no açúcar no sangue e fornecer indicadores de feedback bioquímico. Objetivo: Estabelecer as bases para o estudo das regras de suplementos nutricionais durante exercícios de longa duração, retirando sangue de atletas após o treinamento para determinar as mudanças na glicemia, ajustando e determinando o plano de suplementação nutricional durante o treinamento. Métodos: monitoramos as mudanças na função física e nos indicadores bioquímicos dos atletas durante o treinamento e estudamos as mudanças nesses indicadores bioquímicos e nas funções físicas dos atletas após exercícios de natação de longa distância para organizar cientificamente a intensidade e a carga do exercício durante o período de treinamento. Resultados: As taxas de urina após o exercício não mudaram muito, refletindo a baixa intensidade da carga de exercício. Alterações nos índices de uréia e ácido láctico no sangue após o exercício também confirmaram isso. Durante o período de treinamento, os parâmetros de hemoglobina e hemácias dos atletas estão na faixa ideal, indicando que a função física do atleta está em boas condições. Durante o período de treinamento, a intensidade da carga de treinamento e a carga são razoáveis de acordo com as características da fonte de alimentação da natação de ultra longa distância. Após o treinamento, as mudanças nos indicadores de glicose no sangue refletem que o programa de suplementos nutricionais que formulamos para atletas é razoável e viável. Conclusões: monitorar os indicadores bioquímicos e de açúcar no sangue de nadadores pode ajudar os atletas a organizar cientificamente a intensidade e carga do exercício durante o período de treinamento, conduzir melhor competições em águas abertas na China e organizar treinamento e nutrição cientifica durante o período de treinamento. Estabelecendo as bases para o estabelecimento da teoria dos suplementos nutricionais e da teoria do treinamento para esportes de longa duração. Nível de evidência Il; Estudos terapêuticos: investigação dos resultados do tratamento.

Descritores: Natación; Bioquímica; Glucemia; Eritrocitos; Educación y entrenamiento físico.

\section{INTRODUCTION}

In recent years, the FINA has added open water competitions with a distance of $25-88 \mathrm{~km}$, and the time required to parade is generally from ten hours to dozens of hours. To maintain physical fitness and complete the parade distance, nutrients must be supplemented in time during exercise. ${ }^{1}$ However, because this project has just been launched, there are no reports on how to supplement nutritional supplements during exercise, the type and time of supplementation, and how to arrange exercise intensity and load during the training period has no existing experience and data for reference. According to the metabolic characteristics of ultra-long-distance swimming and energy material utilization and absorption characteristics during exercise, we have formulated a nutritional supplement program for crossing. The purpose of this study is to measure the changes in blood sugar of athletes after training, adjust and determine the nutritional supplement plan during training, and lay the foundation for the study of the nutritional supplement law during long-term exercise. ${ }^{2}$

\section{METHOD}

\section{Research object}

$\mathrm{He}$ is a 36-year-old swimmer with a height of $178 \mathrm{~cm}$ and a weight of $96 \mathrm{~kg}$.

\section{Exercise mode}

Athletes usually train from 8:30 to 11:30 in the morning for 3 hours; the swimming distance is $10000 \mathrm{~m}$, and the swimming speed is 2min-2min20s/100m.

\section{Sampling}

We collected ear blood and urine for remote mobilization after training during standard training, and measured blood lactic acid, blood urea, blood sugar and urine indicators (urine ten items), a total of 12 tests; blood was collected on Monday morning to determine red blood cell parameters, a total of 8 weeks.

\section{Research methods}

We use the enzyme electrode method to monitor athletes' blood glucose, use urine decathlon to detect athletes' urine, use the enzyme electrode method to collect athletes'blood urea and blood lactic acid, and use automatic blood cell counter to monitor red blood cell parameters.

\section{Nutritional supplement}

Daily supplements include pure protein powder, blood-boosting iron, Dao'an solution, glutamine, wheat germ oil, lecithin. The main ingredients of sugar drinks supplemented during exercise: oligosaccharides, vitamins, malic acid, citric acid, etc., are formulated in a particular proportion. ${ }^{3}$ According to the athlete's taste during training and the biochemical index test results after exercise, the sugar drink composition and each component's ratio are adjusted to lay the foundation for determining the nutritional supplement program during the crossing. Supplement a certain amount of sugar drinks at regular intervals during training. According to the biochemical test results after training, the supplement dose and supplement time are adjusted.

\section{GM $(1,1)$ predicts biochemical indicators of athletes}

GM specializes in small samples, imperfect information, and uncertain systems. It excavates and analyzes part of the known information to find out the valuable information hidden in it, to describe and track the law of system changes. The athlete's biochemical index is typical time-series data. Its change process can be regarded as a GM, so GM $(1,1)$ can model and predict the athlete's biochemical index. ${ }^{4}$ We set the original time series of the collected biochemical indicators of athletes as

$X^{(0)}(t)=\left\{x^{(0)}(1), x^{(0)}(2), \cdots, x^{(0)}(n)\right\}$ 
Perform a first-order differential operation on the original data to generate a first-order differential sequence of athletes'biochemical indicators.

$$
X^{(1)}(t)=\left\{x^{(1)}(1), x^{(1)}(2), \cdots, x^{(1)}(n)\right\}
$$

Perform the first-order mean operation on the first-order differential sequence to get the first-order mean sequence.

$$
z^{(1)}(t)=\left\{z^{(1)}(2), z^{(1)}(3), \cdots, z^{(1)}(n)\right\}
$$

Construct a GM $(1,1)$ model based on the first-order mean of the sequence.

$$
\frac{d x^{(1)}}{d t}+a x^{(1)}=\mu
$$

Where: $a$ and $\mu$ are parameters.

Solve the differential equation (4), and obtain the solution of the whitening differential equation predicted by the athlete's biochemical index.

$$
\hat{x}^{(1)}(k+1)=\left\{x^{(0)}(1)-\frac{\mu}{a}\right) e^{-a k}+\frac{\mu}{a}
$$

Where: $k=1,2,3, \cdots, n$.

Calculate the predicted value of the first-order differential athletes biochemical index sequence according to formula (6).

$$
\widehat{X}^{(1)}(t)=\left\{\hat{x}^{(1)}(1), \hat{x}^{(1)}(2), \hat{x}^{(1)}(3), \cdots, \hat{x}^{(1)}(n)\right\}
$$

Obtain the predicted value of the original athlete's biochemical index sequence through the reverse operation of the first-order differential.

$$
\widehat{X}^{(0)}(t)=\left\{\hat{x}^{(0)}(1), \hat{x}^{(0)}(2), \cdots, \hat{x}^{(0)}(n)\right\}
$$

Where: $\hat{x}^{(0)}(k)=\hat{x}^{(1)}(k)-\hat{x}^{(1)}(k-1)$

The prediction residual of the biochemical indicators of the athletes in the GM $(1,1)$ model at time $t$ is.

$$
\varepsilon^{(0)}(t)=x^{(0)}(t)-\hat{x}^{(0)}(t)
$$

According to the above process, we use the $\mathrm{GM}(1,1)$ model to model and predict athletes'biochemical indicators, describing the trend changes of athletes' biochemical indicators.

\section{RESULTS}

\section{Changes in the ten urine indicators of athletes during the training period}

After training, the urine index does not change significantly. Only the sixth test has protein in the urine, and its concentration is only $5 \mathrm{mg} /$ $\mathrm{dl}$, and the bilirubin is only $5 \mathrm{mg} / \mathrm{dl}$. The first and fifth uric acid is $1 \mathrm{mg} / \mathrm{dl}$. The rest are negative results. Changes in urine $\mathrm{pH}$ and specific gravity are also within the normal range. The amount of urine protein produced is proportional to exercise intensity and load. ${ }^{5}$ The changes in urine indicators after exercise reflect that exercise intensity is not significant, consistent with the requirements of long swimming exercise time and relatively small exercise intensity (Table 1).

\section{Changes in blood lactic acid, blood urea, and blood glucose indexes of athletes during the training period}

During exercise, the blood lactic acid value is between 2 and 4.5 $\mathrm{mmol} / \mathrm{L}$, and the blood lactic acid does not change much (Table 2). Because athletes mainly aim to develop long-term aerobic endurance in training, it is required to maintain a particular stroke frequency during training to improve stroke efficiency. In Table 2, the blood lactic acid value is also relatively high several times. This is because the athletes completed the last $3000 \mathrm{~m}$ with a paddleboard to improve the arm's strength. In this way, the exercise intensity is relatively increased, resulting in lactic acid. The increase. ${ }^{6}$ From the perspective of the blood urea index, the whole training period's test value did not change much. The average was $8.29 \pm 0.17 \mathrm{mmol} / \mathrm{L}$, but the blood urea value was at a high level, and the average blood urea in table 3 was $758 \pm 0.15 \mathrm{mmol} / \mathrm{L}$, indicating that the blood urea is also at a higher level at rest. The change of blood sugar after training is relatively stable, basically within the normal range. Although the exercise time is relatively long and the exercise intensity is not significant, there is no hypoglycemia because we pay attention to sugar supplements during exercise.

\section{Changes of Athletes'Red Blood Cell Parameters During Training}

Athletes' red blood cell parameter indicators during the training period have little change, and their hemoglobin has always been at a high level, which has positive significance for aerobic metabolism; hematocrit is higher than expected; red blood cell index (average red blood cell volume, average red blood cell hemoglobin) Content, average

Table 1. Ten indicators of athletes' urine during the training period.

\begin{tabular}{c|c|c|c|c|c}
\hline & PH & PRO & SG & URO & BIL- \\
\hline 1 & 5.5 & - & 1.01 & 1 & - \\
\hline 2 & 6 & - & 1.01 & - & - \\
\hline 3 & 6.5 & - & 1.02 & 1 & - \\
\hline 4 & 5.5 & - & 1.03 & - & - \\
\hline 5 & 6.5 & - & 1.02 & - & - \\
\hline 6 & 6.5 & 5 & 1.03 & - & - \\
\hline 7 & 6 & - & 1.01 & 1 & - \\
\hline 8 & 6.5 & - & 1.03 & - & 0.5 \\
\hline 9 & 6 & - & 1.02 & - & - \\
\hline 10 & 5.5 & - & 1.02 & - & - \\
\hline 11 & 5.5 & - & 1.02 & - & - \\
\hline 12 & 6 & - & 1.02 & - & - \\
\hline
\end{tabular}

Table 2. Athletes'blood lactic acid ( $\mathrm{mmol} / \mathrm{L}$ ) after training during the training period.

\begin{tabular}{c|c|c|c}
\hline & Blood lactic acid & Blood urea & Blood sugar \\
\hline 1 & 3.78 & 8.22 & 3.82 \\
\hline 2 & 2.47 & 8.18 & 3.86 \\
\hline 3 & 2.56 & 8.28 & 4.12 \\
\hline 4 & 4.05 & 8.25 & 4.2 \\
\hline 5 & 2.55 & 8.2 & 3.88 \\
\hline 6 & 2.85 & 8.18 & 4.23 \\
\hline 7 & 3.02 & 8.46 & 4.73 \\
\hline 8 & 2.74 & 8.22 & 4.81 \\
\hline 9 & 3.18 & 8.25 & 4.85 \\
\hline 10 & 4.5 & 8.45 & 4.35 \\
\hline 11 & 3.25 & 8.22 & 4.65 \\
\hline 12 & 3.35 & 8.18 & 4.7 \\
\hline
\end{tabular}

Table 3. Serum urea at rest during training ( $\mathrm{mmol} / \mathrm{L})$.

\begin{tabular}{c|c|c|c|c|c}
\hline & $\mathbf{1}$ & $\mathbf{2}$ & $\mathbf{3}$ & $\mathbf{4}$ & $\mathbf{5}$ \\
\hline Blood urea & 7.84 & 7.62 & 7.39 & 7.55 & 7.51 \\
\hline Average value & \multicolumn{5}{|c}{$7.58 \pm 0.15$} \\
\hline
\end{tabular}


red blood cell hemoglobin concentration) reflects red blood cell deformability, red blood cell aging and blood viscosity, which are in the normal range; red blood cell distribution width (RDW) is a parameter that reflects the volume heterogeneity of surrounding red blood cells, and it is an objective parameter that reflects the different sizes of red blood cells. MCV/RDW and RDW are usually used as screening indicators for hidden iron deficiency. The RDW of athletes during training is basically in the normal range. However, the first measurement was $14.5 \%$, and its MCV/RDW value was 6.50 at a low level, which was significantly lower than the other test values. After reasonable supplementation, the RDW value dropped, and the MCV/RDW value increased significantly, and the average was $8.91 \pm 0.49$ (Table 4).

$\mathrm{HCT}$ is the hematocrit; MCV is the average red blood cell volume; $\mathrm{MCH}$ is the average red blood cell hemoglobin content; $\mathrm{MCHC}$ is the average red blood cell hemoglobin concentration; RDW is the red blood cell distribution width.

Table 4. Changes of Athlete's Red Blood Cell Parameters During Training.

\begin{tabular}{c|c|c|c|c|c|c|c|c}
\hline & $\mathbf{1}$ & $\mathbf{2}$ & $\mathbf{3}$ & $\mathbf{4}$ & $\mathbf{5}$ & $\mathbf{6}$ & $\mathbf{7}$ & $\mathbf{8}$ \\
\hline $\mathrm{RBC1012/L}$ & 4.65 & 4.52 & 4.65 & 4.75 & 4.76 & 4.82 & 4.75 & 4.64 \\
\hline $\mathrm{Hbg} / \mathrm{L}$ & 148 & 156 & 163 & 165 & 167 & 158 & 170 & 165 \\
\hline $\mathrm{HCTI} / \mathrm{L}$ & 0.438 & 0.435 & 0.44 & 0.456 & 0.468 & 0.452 & 0.465 & 0.448 \\
\hline $\mathrm{MCVfl}$ & 94.2 & 96.3 & 94.6 & 96 & 98.3 & 93.8 & 97.9 & 96.5 \\
\hline $\mathrm{MCHpg}$ & 31.83 & 34.5 & 35.1 & 34.7 & 35.1 & 32.7 & 35.8 & 35.6 \\
\hline $\mathrm{MCHCg} / \mathrm{L}$ & 337.9 & 358.6 & 370.4 & 361.8 & 356.8 & 349.6 & 365.6 & 368.3 \\
\hline $\mathrm{RDW} \%$ & 14.5 & 11 & 10.6 & 11.2 & 10.5 & 10.9 & 11.8 & 9.8 \\
\hline $\mathrm{MCV} / \mathrm{RDW}$ & 6.5 & 8.75 & 8.92 & 8.57 & 9.36 & 8.61 & 8.3 & 9.85 \\
\hline
\end{tabular}

\section{DISCUSSION}

\section{Changes in urine indicators during training}

From the test results during training, urine-specific gravity is in the normal range. This is because athletes drink a certain amount of sugary drinks at intervals during training. On the other hand, Athletes are engaged in swimming in the water. The water quickly absorbs the heat generated during the exercise. Therefore, they do not need to sweat or perspire very little during the exercise. Therefore, dehydration generally does not occur. Other urine indicators, such as uric acid and bilirubin, are positive after training, but the values are shallow, and the rest are harmful. This also reflects that the load intensity is not significant.

\section{Changes in blood lactic acid, blood urea, and blood glucose indexes of athletes during the training period}

This shows that our nutritional supplement program for athletes during the training period is practical and feasible. It also shows that the dietary nutrition program we are formulating for them is reasonable. The change of blood sugar during training is basically in a relatively stable upward trend. According to the initial blood sugar changes, blood sugar after training is at the lower limit of the normal range. We adjusted the composition, amount and time of the beverage in the nutritional supplement program during training and achieved good results.

\section{The impact of sports training on athletes' red blood cell parameters}

The increase of RDW reflects a good screening index for recessive iron deficiency anemia to a certain extent. The MCV/RDW ratio is a more sensitive indicator that may reflect recessive iron deficiency anemia. The average

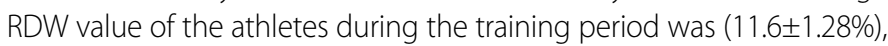
which was basically in the normal range, and the MCV/RDW value averaged $8.61 \pm 0.92$. Still, the first measured value RDW was $14.5 \%$, and the MCV/RDW ratio was 6.5 , which indicates that there may be recessive iron deficiency anemia. By supplementing athletes with elevated blood iron and whey protein, their RDW value dropped back to normal, and the MCV/ RDW value rebounded, with an average of $8.91 \pm 0.49$, suggesting that the iron metabolism disorder may be corrected.

\section{CONCLUSION}

There is little change in blood and urine indexes after exercise during the training period, indicating that the exercise intensity is relatively small, which may be a long-term exercise feature. The aerobic metabolic capacity of athletes has significantly improved, which shows that the exercise intensity and exercise load during the training period are arranged reasonably. The training is aimed at the energy supply characteristics of ultra-long-distance swimming.

All authors declare no potential conflict of interest related to this article

AUTHORS' CONTRIBUTIONS: Each author made significant individual contributions to this manuscript. Chunying Zhao: writing and performing surgeries; Chunying Zhao: data analysis and performing surgeries, article review and intellectual concept of the article.

\section{REFERENCES}

1. Bezugla VV, Gunina LM, Vinnichuk YD, KlapchukVV. Influence of cardonat on indicators of biochemical and hormonal homeostasis in sportsmans with cardiomyopathy after physical overload. Eastern Ukrainian Medical Journal. 2019;7(2):148-58.

2. Yang $W$, Sun $H$, Wang Z. Local body movement monitoring of physiological and biochemical indicators in mice. Revista Científica de la Facultad de Ciencias Veterinarias. 2020;30(2):738-48.

3. Kopiczko A, Łopuszańska-Dawid M, Gryko K. Bone mineral density in young adults: the influence of vitamin D status, biochemical indicators, physical activity and body composition. Archives of Osteoporosis. 2020;15(1):1-9.
4. Ovcharenko S, Yakovenko A, SydorchukT, Stepanova I, Pikiner O. Criteria for assessing the level of physical fitness and physical state of football players with cerebral paralysis, taking into account their sports classes. Pedagogy of Physical Culture and Sports. 2021;25(2):125-31.

5. Filar-Mierzwa K, Marchewka A, Bac A. Effects of different exercise interventions on selected hematological, rheological, and biochemical indicators in older women. Folia Biologica. 2020;68(1):35-44.

6. Shan L. Sports load detection method for outdoor rock climbing athletes in alpine eco-environment Ekoloji. 2019;28(108):2015-9. 